\title{
JAMURO RELIGIOUS FACTORS: PERSPECTIVE OF ISLAMIC EDUCATIONAL PSYCHOLOGY
}

\author{
${ }^{*}$ Jony Muhandis, 2 Muhammad Nurul Yamin, 3 Syarifan Nurjan \\ 1Universitas Muhammadiyah Yogyakarta, Indonesia, 2Universitas Muhammadiyah Ponorogo \\ 1*jony.muhandis@yahoo.co.id, 2moehyamien@umy.ac.id, 3syarifanur@gmail.com
}

\section{ARTICL E IN FO}

Article history

Received $11 / 1 / 2020$

Revised 9/2/2020

Accepted 10/3/2020

Keywords

Religious

Jamuro

Psychology

Islamic Education

Educational Psychology
ABS TRACT

Jamaah Muji Rasul Surakarta goes through the religious process of Sufi life, which is to cleanse themselves from the impurities of the heart and keep away from the low behavior in life to always worship God. This study aims to describe the factors that influence the diversity of the Muji Rosul Jamaat perspective in the psychology of Islamic education and its contribution to Islamic education. This study uses a qualitative research approach with the perspective of Islamic educational psychology that uses descriptive analysis method. The results of the study illustrate that the factors that influence religious diversity are the intensity of muji Rosul through tabligh activities, tahlilan and shalawatan able to strengthen the diversity of worshipers who are carried out routinely every Monday Pon, tarling, gebyar maulid, evening compensation, raising funds for the construction of mosques and musholla, white clothes or tend to be bright, because of the colors favored by the Prophet's Kanjeng, and colors that are simple and easy to obtain, look clean and there is no difference between worshipers, analyzing human behavior with religious knowledge and baraka.

This is an open access article under the CC-BY-SA license.

\section{INTRODUCTION}

Religious movements or religious organizations is an organized effort to spread new religions, or new interpretations of existing religions, with internal and external dimensions as aspects of organization in religion (Nottingham, 1985). This all understands that every religion must teach and emphasize faith or belief which is appreciated through various media including organizations, and becomes an interesting phenomenon to be studied in the practice of religious people (Baidowi, Murtono, \& Fadholi, 2014) in daily life.

The city of Surakarta has a variety of organizational groups, the development and movement of organizational groups exist through preaching activities following their understanding by bringing together elements of shalawat, preaching or recitation. Jamuro is one of the new movements that attracts attention by 
promoting indigenous psychology in its religious development, a movement that was born in 2005 pioneered by K.H. Karim Ahmad (Gus Karim) and named Jama'ah Muji Rasul.

Jama'ah Muji Rasul (Jamuro) emphasizes praising the Prophet utilizing shalawat and reading the book of Barjanji (promised) as a means of diversity. The unique side of Jamuro, which combines promise, "Shalawat with hadrah (rebana) with recitation that causes the event to bring in thousands of worshipers from across Surakarta and beyond (Nurjan \& Muhandis, 2019). Religious activities and the role of religious behavior can provide inner peace of life processes, as in Figure 1. Below.

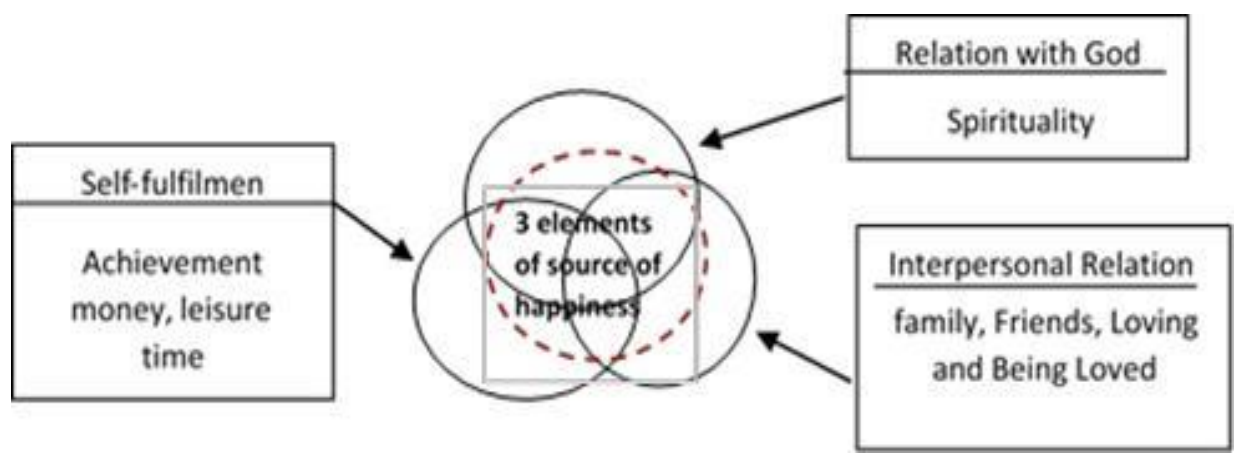

Figure 1.

Three Elements of Happiness (Primasari \& Yuniarti, 2012).

Religious activities look more at aspects in the depth of the conscience of the person, a deep personal attitude, when a sense that includes totality (including ratio and human taste) into the human person. Because of that religiosity is more than religion that looks formal and official in daily behavior (Muhaimin, 2002). Religious behavior breaks down religious beliefs (Mariene, et.,al., 2020), religious practices, religious experience, appreciation of religious diversity, and religious knowledge. The definition of religion, religiosity, and religion experience differences with certain pressures, namely religion is a belief system of the sacred rules with all its rules and rituals, while religiosity is the application of belief in the form of behavior. While religion is everything related to religion. This study focuses on the religious factors of Jamuro, psychological perspective of Islamic Education in Surakarta, Central Java. This study aims to describe the factors that influence the religious diversity of Muji Rosul with a psychological perspective of Islamic education that contributes to Islamic education.

\section{METHODS}

This study includes field research (Moelong, 2014), with a qualitative research approach with the perspective of Islamic education psychology using descriptive analysis methods, which use the following steps: Finding Data inclunding organizing data accordingly; Reading the entire text and making groups; Describe 
someone's religious experience; Classifying various data into themes; Interpreting data; Present data to the form of discussion. The objects and subjects of this study are Research object is the religious factors of Jamuro Surakarta members in the perspective of Islamic educational psychology.

The research subjects were pilgrims Jamuro Surakarta and Jamuro management, members of the congregation Jamuro with an age limit of 30 years and above (the age of adulthood) and had one year to attend Jamura activities. Technical data collection using: a) making observations, conducting interviews with leaders, members of the congregation and management, hereinafter referred to as informants; b) library research, i.e. gathering and quoting, verses and hadith as well as expert opinions from books and books that deal with the problem being discussed, namely Barzanji, Maulid Dzibâ and certain Nasyid books. Qualitative analysis requires researchers to conduct activities simultaneously with data collection, data narrative and report writing (Creswell, 1994). So that in analyzing data is not separate from data collection. The data processing scheme is broken down in Figure 2. Below:

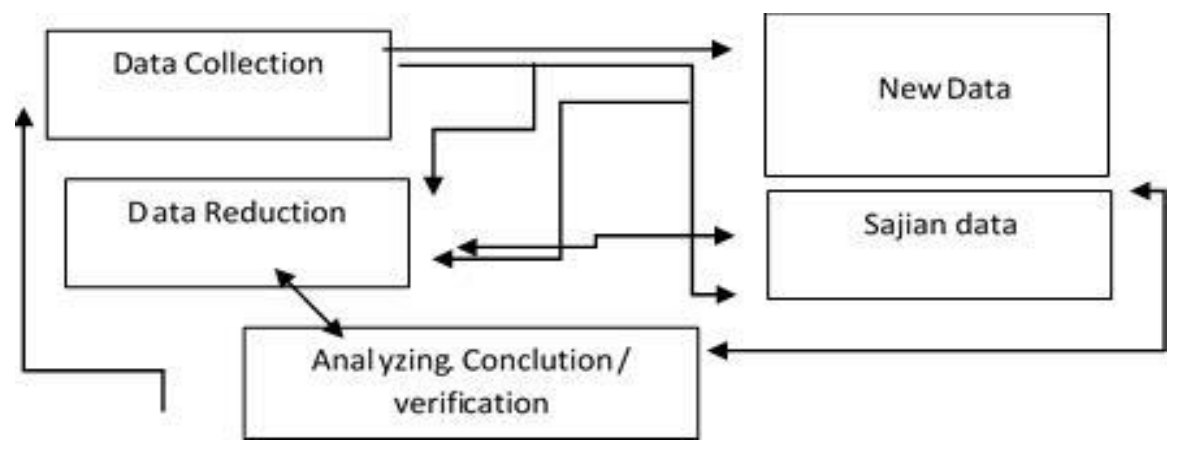

Figure 2 .

Data Management Scheme

Data Processing Scheme above illustrates that the data obtained from interviews, observations, and documentation. The data is collected to be presented in the form of a narrative about the diversity of Jamuro, then reduced by selecting, analyzing, and giving conclusions about the factors of diversity and its contribution in the psychology of Islamic education. The results of the analysis and conclusions from the field carried out the simplicity of the data, then conducted discussions in the form of Jamuro religious factors and contributions in the world of psychology of Islamic education with the perspective of Psychology of Islamic Education.

\section{RESULT AND DISCUSSION}

\section{A. History of Jamuro Surakarta}

The congregation of Muji Rosul (Jamuro) was born or established in Surakarta, declared on April 21, 2005. The organization or congregation of muji rosul originally came from an awareness of religious leaders in the Tegalsari 
Mosque in Surakarta about the distance of the next generation of religious behavior that well, reduced love for the Prophet and Islamic leaders. And the growing abandonment of Islamic culture (Arifin, Juharyanto, Mustiningsih, \& Taufiq, 2018), it is feared that generations will lose their identity as Muslims and as Javanese. Jamuro was declared on April 21, 2005 during the salawat parade in West Square by Mr. Joko Widodo when he was the Mayor of Surakarta. Some religious leaders gathered to form an activity with the initial activity of reciting the Quraysh or sema'an of the Quraysh, which is reading alQur'an at the Tegalsari Mosque according to the narration Idris Shofawi that concern for the next generation who is getting away from love and tradition calls the prophet or the tradition of reading salawat.

The tadarus al-Qur'an activity was developed by reading awatanalawatan, namely reading Barzanji. Initially, the activity of success was carried out after reading the Qur'an. But in its development carried out at a separate time because the number of followers of recitation. In the explanation K.H. Idris Sofawi about the origins and development of Jamuro Surakarta: "At first the Qur'an recitation group was only attended by a few people, but after the development of the pilgrims who followed the downloader had to have a large place, because to accommodate the worshipers who were present and had to involve many people. Finally, we get together to read al-Qur'an and also read al-Barzaji. Well, only about nine to ten people, but only my friends. This activity is carried out in turn from one member to another, from this Friday to here, Friday, Friday and so on. Finally, everyone who invites always invites friends, one or two. The term "introduce salawat by reading" it was Barzanji which was carried out by our predecessor"

Since 2007, approaching the month of Mawlid in $1427 \mathrm{H}$ to fill activities from the night of the 1 Mawlid to the night of the 12th, a committee was set up to arrange the downloaders and their preachers. The committee for organizing the title of Mawlid for 12 nights in the month of Mawlid $1427 \mathrm{H}$. was formed in a deliberation at the house of $\mathrm{Mr}$ Samachin in the following order of arrangement: Chairman Ibrahim Asfari, Secretary: Samachin, Treasurer: Musbi. Giving names to this activity group, there are several suggestions for giving names including the Prophet Muhammad and Muhibbin, but when Abdul Karim or Gus Karim proposed a name Jamuro as short for the word Jama'ah Muji Rosul, with the hope that this activity (the activity of reading alalawat) will soon room from the word njamur njamur njurur, as he said, he is more in hope of the progress of the study group in every heart and society.

\section{B. Jamuro Religious Behaviour}

Jamuro religious behavior is an act carried out in his life both personally and in groups because of understanding religion, the act is a solution to the problems of life and as evidence of his faith. The intended behaviors include: Birth which is the desire and purpose of the marriage between a woman and a 
man, before the birth of the ritual is held reciting certain in al-Qur'an both personally "parents" or in congregation. The reading of Barzanji is done in the market or five days, from the night after the baby is born until the night of 5 (five), or when aqikahan is done. But between the reading of Barzanji and akikahan which is more certain to be done is the reading of Barzanji, because as part of the rite of prayer also does not cost much by inviting someone to read it if they have not been able to hold aqiqah. In certain circumstances the reading of Barzanji and aqiqah is carried out another time after being able to carry out aqiqah. Because it requires a lot of costs, while the initial cost is usually used for the needs of labor costs at the maternity clinic.

Education plays an important role in the process of human life, the ability to understand themselves and overcome life's problems in the present and the future. In the case of education Jamuro Surakarta members as part of the community who understand the importance of education, put the education process as the main part. For the direction of education in the Surakarta community for Muslims, specifically as expressed by Suparmin, Sayimuri and Gus Karim as follows: In terms of how to educate religion and knowledge of their children are grouped in four things: 1) Education in reading Arabic letters and basic religious knowledge, children are taught in Mushalla or Mosque or certain places such as in schools or in Islamic boarding schools; 2) Formal education now tends to be integrated Islamic schools (IT), Integrated Islamic Elementary Schools, Integrated Islamic Madrasas, Integrated Islamic Junior High Schools and Integrated Islamic High Schools. Furthermore, to Madrasah Ibtidaiyah, Madrasah Tsanawiyah or Madrasah Aliyah State or private, which is preferred near the Islamic Boarding School or which is integrated with Islamic Boarding School; 3) Continuing non-formal education is boarding school, boarding. The progress of Islamic education and awareness of religious diversity is very good; 4) Religious education is carried out in studies in study groups. The practice of increasing the quality of knowledge and the deepening of religion.

While in marriage there is an event to determine a good prospective partner, determine the wedding day, carry out the wedding, legalize the wedding and finally the reception or wedding party. When the event of death occurred many things were done, including: (1) reciting Surah Yasin, (a) saying the sentence tarje innalillahi wainnailaihi râji'un. (b) reciting the Talqin sentence when he was nearing his death or at the tomb, (c) performing Janazah prayers repeatedly with different imams and worshipers, (d) holding tahlil and yasinan

(e) holding a departure ceremony (f) an apology and statement if there is still a debt and credit bond between the deceased by the family or representing the sahibul calamity, so that it is resolved with the family. The name of the deceased, al-magfur is used to honor "janazah", in the community there are also other designations such as: jenate, swargi and, sergi which indicates that a person with that name has passed away to the world. Apart from that, 
brobosan customs and other traditions sometimes have implementations, sometimes not.

"Belief in the existence of Allah, I am referring to God use the term Gusti. Gusti Allah, Gusti Allah, Pangeran." All contain the intention of the Essence which has more power. This can be seen in talks and when sermons and speeches often use these terms. Belief in angels, this belief in angels is seen when doing tahlilan. In reaching closeness with angels who always carry out their duties. Honesty and maintaining good deeds despite not guaranteeing all members of the congregation to be honest and fair in charity, but in every lecture and appeal always recommended to always behave properly. Recognition of the books of God by reading the Qur'an that there are several motivations including seeking barâka, studying, memorizing, and so forth.

Recognition of the existence of especially the Prophet Muhammad, marked by: 1) Embed the word "sayyid" as respect and love; 2) Holding the birthday of the Prophet Muhammad; 3) Respond, every time you hear the name of the prophet Muhammad SAW mentioned; 4) Establishment of recitation-recitation assemblies and $d z i k r$ assemblies with the main activity of reading salawat with a large number of worshipers, and not infrequently one person can join another group. Confidence in the end of the day is shown by the requests for intercession and prayers and salvation which is always held both individually and in groups. Obedience performs compulsory and sunnah worship. Practicing remembrance as practice.

Taqdir Good and Bad, factors that influence the diversity of the Muji Rosul Jamaat include: khusyu' and independence. Khusyu' and independence, as a focal chanter of the salawat alternately, with good sound quality because they had been champions of Qori'. Prioritizing adversity in chanting the hearts and when thinking, simplicity. The value of beauty which is the instinct of pleasure for all humans. The ability to cultivate focal in chanting sentences can affect the feelings and mentality of others. Like the masterminds who are good at processing their voices will surely have a lot of fans.

Likewise, the recitation of salawat poems in every Jamuro activity will be sung by chosen people so that it is not boring. Mubalig who are constantly changing in addition to being able to provide religious insights with different backgrounds are also different ways used in giving their da'wah, so that pilgrims are not bored and always have the motivation to always be present. Comfort in carrying out the rituals of worship is very important, because it can lead to the level of discomfort and make inner peace. The feeling that can be found with the melodious voice, authority, charisma and even lived with closed eyes is the sincerity of someone in finding solemn degrees. Longing and a sense of peace with oneself and others and the environment are indicators of one's kindness (Chaer, 2017). 
Obedience and discipline, the attitude of the Jamaat when attending all events must be calm, maintaining order and the smooth running of the event. Obey the values of politeness according to tradition, to show all people that Jamuro is good, not waving any flag, or dancing. All hidmad. The cleric or priest Kyai who read Barzanji also hidmad read it without giving "loving". Polite and humble attitude, boardman, ngajeni marang liyan is a personality that is highly prioritized by Javanese people. Ajining diri saka busono, clothing can be interpreted everything that appears in a person. If you can put yourself as best you can on him, then someone will be a good and respectable person. Ethics nguwangake wang liya, a tight grip of the Javanese.

In every activity Jamuro never gives love by being thrown. Giving in the guidance of Islam is required not to be painful to the person who receives it, so giving using being tossed or locked up is not recommended by Islamic teachings (El-Seedi et al., 2019), nor will Javanese give food in this way. Especially concerning providing food certainly given in a good way, because it will involve the dignity of others. Knowing the nature of oneself becomes the medium of introduction to know his God (Setiawan, Tajab, \& Chaer, 2019).

Consistent, routinely every Monday, Pon, tarling, a maulid event, a night of compensation, raising funds for the construction of mosques and prayer rooms, recitation of fellow management, group recitation, fund raising for propaganda radio. The certainty of the time of the implementation of the activity also greatly influences and motivates worshipers to always carry out the event routinely. Repeated behavior becomes easy to remember. Making himself has a regular routine. Then the behavior that is repeated makes a habit, so that if one day do not do it again will appear regret.

Clothing, Jamuro in every activity wears white or tends to be bright, because the colors favored by Kanjeng Nabi, and colors that are simple and easy to obtain, look clean and there is no difference between pilgrims, caretakers or ulamak. Simplicity is easy for everyone to do, so this kind of preaching will have great success, people will easily do and imitate the kindness offered. Symbols that are easy to see and easy to remember. The goal is that the community can easily carry out good deeds, and if one day the condition of his faith is in crisis by seeing these symbols his faith returns easily, far from fanatic (Setiawan, 2016). Likewise the messages given from the palace in the form of symbols, such as mosque position, market position, aloon-aloon position, giving the term aloon-aloon, ringin brackets, gate and so on, all contain messages from the king or the government to the people because the king is not possible always verbally reminded the people one by one.

Thought and tahlil, salawat and recitation and the reading of Barzanji, These are all things that are loved by the congregation, as a religious event, the promises are very favored, especially at the time of mahalul qiyam, there as if the blessing of the Kanjeng Nabi the Prophet and Gusti Allah is very close. By listening to 
religious lectures or recitals, also able to awaken faith, awaken the spirit of aqeedah and the rise of another knowledge. Tahlil recitation procession and salawatnya, tahlilan function is to pray for the ancestors in the hope of visiting will also be prayed by children and grandchildren and fellow Muslims, while salawatan as a sign of gratitude (Noviati, 2017)and love to Kanjeng Nabi, with the hope that we will be recognized as his people.

Social suggestion, namely the presence of other people around him will be able to influence diversity. In things that are not mastered it will be helped by other people who read it, psychologically there will also be a feeling of shame if not doing as others do. All environmental influences in the form of society, friends, traditions, moral, emotional conflicts and, unmet needs factors will produce positive religious expressions (Felix, Hinsch, Rauschnabel, \& Schlegelmilch, 2018). When someone is going to do something that is deviant but is discovered by other Jamuro members, one will surely feel ashamed and not even deviate. Peace and kindness need to be taught to achieve a good and superior person (Suud, 2018).

Intellectual factors, understanding of religious knowledge and other sciences will be able to analyze the truth of religious behaviour under the Shari'a by analyzing and searching for its legal basis. Explanation of propaganda material by clerics who have charisma in the community is also very influential (Rahman, Z. A., \& Shah, I. M. (2015). Language that is simple, fluent, relaxed and familiar, makes it easy for pilgrims to grasp the expected noble values. In the tradition of the tarekat it is a virtue for a Muslim to be gentle. For example, in Tarekat Syattariyah known as dzikir martabat 7 as a medium to get closer to God with maximum spiritual achievement (Setiawan, 2015).

Barokah, when gathering with scholars, fellow Muslims to think and pray are expected to get blessing. Bless the world and the akhirat. The blessing of the world is in the form of good social relations, while blessing in the form of intercession from the Prophet Muhammad Saw alleviated or removed the sins that were already done. Needs, there are several needs in this regard, including the need to gather, the need to worship together, increase knowledge, politics, economics, responsibilities and much more.

\section{The Contribution of Jamuro Religion to Islamic Education.}

Religious contribution of Jamuro Surakarta to Islamic education. The first thing that can be noted from the book which is the main reference in salawat. In the book al Barzanji in addition to containing the history, praise, and prayers. The values implicit in the string of poems Barzanji besides the beauty of the composition of the poem, also the content of the message: 1 . Morals of the Prophet in the Book of Mawlid al-Barzanjî. 2. Moral Analysis of the Prophet Muhammad. In the Book of Mawlid al-Barzanjî Natsr in the Book of Mawlid alBarzanjî written stages of behavior (morals) or the development of behavior or personality of the Prophet Muhammad. Which can form a noble person. There 
are: a. Self aware, b. Courteous and forgiving, c. Fair and wise behavior, d. Patient behavior, 3. Educational Values in Barzanji Poetry include: a. Good selection of educators and environment, b. Honesty. Honesty education becomes very important in life (Suud \& Madjid, 2020). c. Ahlak's education in finding a life partner. d. Age appropriate education.

\section{CONCLUSIONS}

This research can be concluded as follows: first, factors that influence the diversity of Jamuro Surakarta are: in the form of solitude, reading readiness, obedience and discipline, routines, clothing, remembrance and tahlil, social suggestions, understanding of Islam, and needs. Second Jamuro's contribution to Islamic education, in the form of: 1) Prophet's morals in the book of Barzanji; 2) Analysis of the Prophet's morals namely introspective, polite and forgiving, fair and wise behaviour, and patient behavior; 3) The value of education in poetry Barzanji, namely the selection of educators and a good educational environment, honesty, and education according to human age.

\section{REFERENCE}

Alon Tal, Dorit Kerret. (2020). Positive psychology as a strategy for promoting sustainable population policies, Heliyon, 6(4), https://doi.org/10.1016/j.heliyon.2020.e03696.

Arifin, I., Juharyanto, Mustiningsih, \& Taufiq, A. (2018). Islamic Crash Course as a Leadership Strategy of School Principals in Strengthening School

Organizational Culture. SAGE Open, 8(3). https://doi.org/10.1177/2158244018799849

Baharuddin, E. Bin, \& Ismail, Z. B. (2015). 7 Domains of Spiritual Intelligence from Islamic Perspective. Procedia - Social and Behavioral Sciences, 211, 568-577. https://doi.org/10.1016/j.sbspro.2015.11.075

Barrientos-Fernández, A., Sánchez-Cabrero, R., Arigita-García, A., MañosoPacheco, L., Pericacho-Gómez, F. J., \& Novillo-López, M. Á. (2019). Measurement of different types of intelligence (general, verbal vs. nonverbal, multiple), academic performance and study habits of secondary students at a Music Integrated Centre. Data in Brief, 25, 104124. https://doi.org/10.1016/j.dib.2019.104124

Baidowi, A. A., Murtono, \& Fadholi, M. Y. (2014). Suhuf. Journal of Psychology, 26(2).

Chaer, M. T. (2017). Islam dan Pendidikan Cinta Damai. Istawa: Jurnal Pendidikan Islam, 2(1), 73-94.

Creswell, J. W. (1994). Research Design Qualitative and Quantitative Approaches. London: Sage Publications.

El-Seedi, H. R., Khalifa, S. A. M., Yosri, N., Khatib, A., Chen, L., Saeed, A., ... Verpoorte, R. (2019, October 28). Plants mentioned in the Islamic Scriptures 
(Holy Qur'ân and Ahadith): Traditional uses and medicinal importance in contemporary times. Journal of Ethnopharmacology, Vol. 243, p. 112007. https://doi.org/10.1016/j.jep.2019.112007

El-Seedi, H. R., Khalifa, S. A. M., Yosri, N., Khatib, A., Chen, L., Saeed, A., ... Verpoorte, R. (2019, October 28). Plants mentioned in the Islamic Scriptures (Holy Qur'ân and Ahadith): Traditional uses and medicinal importance in contemporary times. Journal of Ethnopharmacology, Vol. 243, p. 112007. https://doi.org/10.1016/j.jep.2019.112007

Felix, R., Hinsch, C., Rauschnabel, P. A., \& Schlegelmilch, B. B. (2018). Religiousness and environmental concern: A multilevel and multi-country analysis of the role of life satisfaction and indulgence. Journal of Business Research, 91, 304-312. https://doi.org/10.1016/j.jbusres.2018.06.017

Jan M.A. de Vries, Fiona Timmins, (2012). Psychology teaching in nursing education: A review of and reflection on approaches, issues, and contemporary practice, Nurse Education in Practice, 12, (6), 316-321, https://doi.org/10.1016/j.nepr.2012.03.007.)

Kyle J. Emich, Kurt Norder, Li Lu, Aman Sawhney. (2020). A comprehensive analysis of the integration of team research between sport psychology and management, Psychology of Sport and Exercise, https://doi.org/10.1016/i.psychsport.2020.101732.

Miriane Lucindo Zucoloto, Carolina Cunha Bueno-Silva, (2020). Livia Borges Ribeiro-Pizzo, Edson Zangiacomi Martinez, Knowledge, attitude and practice of blood donation and the role of religious beliefs among health sciences undergraduate students, Transfusion and Apheresis Science, https://doi.org/10.1016/j.transci.2020.102822.

Moelong, L. J. (2014). Qualitative Research Methods, Revised Edition. Bandung: PT. Youth Rosdakarya.

Muhaimin. (2002). Paradigm of Islamic Education (Efforts to Effective PAI in Schools). Bandung: Youth Rosdakarya.

Nottingham, E. K. (1985). Religion and Society. Jakarta: CV. Rajawali.

Noviati, N. P. (2017). Gratitude Training to Reduce Job Stress on People with Work-Family Conflict. Jurnal Psikologi Islam, 4(2), 100-106.

Primasari, A., \& Yuniarti, K. W. (2012). What make teenagers happy? An exploratory study using

indigenous psychology approach International Journal of Research Studies in Psychology, 1(2), 53-61

Rahman, Z. A., \& Shah, I. M. (2015). Measuring Islamic Spiritual Intelligence. Procedia Economics and Finance, 31, 134-139. https://doi.org/10.1016/s22125671(15)01140-5

Russell Craig, Adam Cox, Dennis Tourish, Alistair Thorpe. (2020). Using retracted journal articles in psychology to understand research misconduct in the social sciences: What is to be done?, Research Policy,49 (4), https://doi.org/10.1016/j.respol.2020.103930. 
Setiawan, W. (2015). Prosesi Baiat Jamaah Tarekat Sattariyyah; Sebuah Kajian Fenomenologi. AL-MURABBI: Jurnal Studi Kependidikan dan Keislaman, 1(2), 63-76.

Setiawan, W. (2016). Fanatisme Dalam Berorganisasi. Muaddib: Studi Kependidikan dan Keislaman, 4(1), 20-44.

Setiawan, W., Tajab, M., \& Chaer, M. T. (2019). Ruh, Soul, Heart, Mind, and Body in the Perspective of Islamic Educational Psychology. Paper presented the WESTECH.

Suud, F. M. (2018). Pendidikan Kedamaian di Era Digital (Telaah Model Forgiveness dalam Psikologi Islam). FIKROTUNA: Jurnal Pendidikan dan Manajemen Islam, 7(1), 694-716. doi:10.32806/jf.v7i1.3170

Suud, F. M., \& Madjid, A. (2020). Honesty: A Multidimensional Study as Motivation for National Character Building. Hayula: Indonesian Journal of Multidisciplinary Islamic Studies, 4(1), 99-116. doi:10.21009/hayula.004.1.06

Syarifan Nurjan, \& Muhandis, J. (2019). Jamuro and Islamic Education (Indegenous Psychology Perspective). In: ICEPP: Diversity in Education, School of Postgraduate Studies, Indonesian University of Education.

Noviati, N. P. (2017). Gratitude Training to Reduce Job Stress on People with Work-Family Conflict. Jurnal Psikologi Islam, 4(2), 100-106. 